\title{
Total synthesis of hydroxymethyl isonucleosides as potential antiviral agents
}

\author{
Vasu Nair $^{*+}$ and Byoung-Kwon Chun ${ }^{+}$ \\ * Department of Pharmaceutical and Biomedical Sciences, R. C. Wilson PH, \\ University of Georgia, Athens, GA 30602-2352 \\ + Department of Chemistry, University of Iowa, Iowa City, IA 52242 \\ E-mail:vnair@rx.uga.edu
}

(received 24 Jan 03; accepted 24 Mar 03; published on the web 09 Apr 03)

\begin{abstract}
Hydroxymethyl isodideoxynucleosides, designed as potential antiviral agents, have been synthesized through development of a multi-step procedure starting from furan and cyanovinyl acetate. Key steps in the synthesis include a Diels-Alder reaction, oxidative cleavage of alkene, a Mitsunobu reaction, stereospecific introduction of amino group and nucleobase construction.
\end{abstract}

Keywords: Total synthesis, purine and pyrimidine isonucleosides

\section{Introduction}

Isomeric dideoxynucleosides as antiviral agents have been the subject of intense investigation in our laboratory ${ }^{4}$ and have also been studied by others. ${ }^{5}$ Work in our laboratory led to the discovery of $4(S)$-(adenin-9-yl)-2(S)-hydroxymethyltetrahydrofuran [(S,S)-isoddA] (1, Figure 1) which exhibits potent anti-HIV activity against HIV-1, HIV-2, and HIV-resistant strains. ${ }^{6}$ Its triphosphate is among the strongest known inhibitors of HIV reverse transcriptase. In the design of new structures that may have anti-HIV activity, we decided to explore analogues of this lead compound by introducing functionalized substituents into the sugar moiety. Introduction of an additional hydroxymethyl group was of interest, not only because of the observation of anti-HIV activity associated with isomeric nucleosides in which the adenine ring and the $-\mathrm{CH}_{2} \mathrm{OH}$ have cis-1,3- and 1,2-relationships (2, Figure 1), ${ }^{6,7}$ but also because of the known antiviral activity of natural oxetanocin and its ring expanded analog which bear an additional $-\mathrm{CH}_{2} \mathrm{OH}$ group. ${ }^{8}$ The molecules targeted for synthesis (3-5) are shown in Figure 1. 


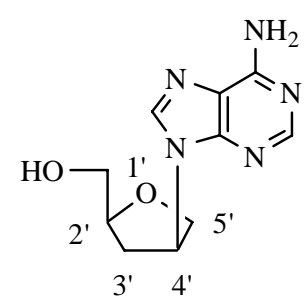

1

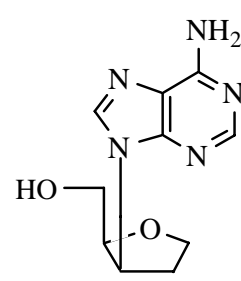

2

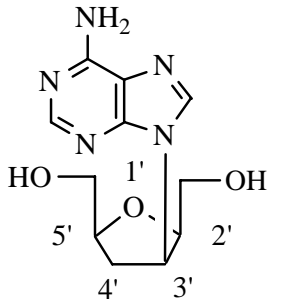

( \pm ) 3

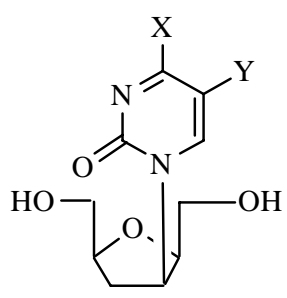

( \pm ) $4 \mathrm{X}=\mathrm{OH}, \mathrm{Y}=\mathrm{H}$

( \pm ) $5 \quad \mathrm{X}=\mathrm{NH}_{2}, \mathrm{Y}=\mathrm{H}$

Figure 1

\section{Results and Discussion}

For the preparation of the proposed hydroxymethyl isodideoxynucleosides, the initial step of the procedure involved a Diels-Alder reaction (Scheme 1). Thus, furan 6 was treated with 1cyanovinylacetate (7) and catalyst, zinc diiodide, and stirred at room temperature for 4 days to give an adduct 8 in high yield (70\%). ${ }^{9,10}$ Adduct 8 was converted to ketone $\mathbf{9}$ by sequential treatment with $1 \mathrm{~N}$ potassium hydroxide and formaldehyde. ${ }^{10}$ Ketone $\mathbf{9}$ was reduced stereoselectively to alcohol $\mathbf{1 0}$ by sodium borohydride in methanol in $65 \%$ yield from $\mathbf{8}^{11}$ However, direct reduction of $\mathbf{8}$ with sodium borohydride gave even higher yields of $\mathbf{1 0}$ (89\%) and with the same stereoselectivity. Protection of compound $\mathbf{1 0}$ with tert-butyldimethylsilyl chloride gave intermediate 11 (83\%).

An attempt to convert olefin 11 to a dialdehyde $\mathbf{1 3}$ in one pot, using osmium tetroxidesodium periodate system, ${ }^{1}$ did not give a clean reaction. Therefore, compound $\mathbf{1 1}$ was converted to the dialdehyde $\mathbf{1 3}$ in two discrete steps. First, olefin $\mathbf{1 1}$ was dihydroxylated to the triol derivative 12 using catalytic amounts of osmium tetroxide and stoichiometric amounts of $\mathrm{N}$ methyl morpholine $N$-oxide (88\% yield). ${ }^{1}$ Purified 12 was treated with sodium periodate in tetrahydrofuran-water to give the dialdehyde 13, which was immediately reduced to the triol derivative 14 in $76 \%$ yield by sodium borohydride. Because the initial Diels-Alder reaction produced a racemic adduct $\mathbf{8}$, the sequence of reactions from $\mathbf{8}$ would produce the racemic triol derivative 14. 
<smiles>C=C(C#N)OC(C)=O</smiles>

6

7

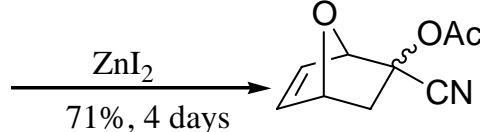

8

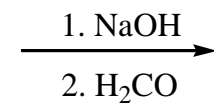

12

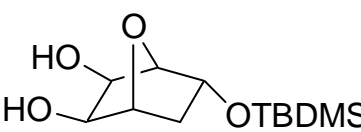

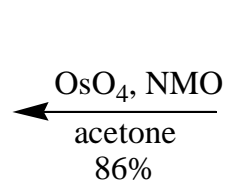

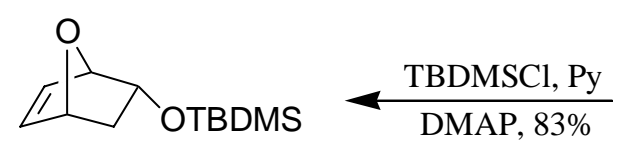

11

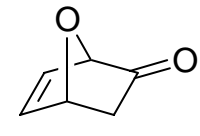

9

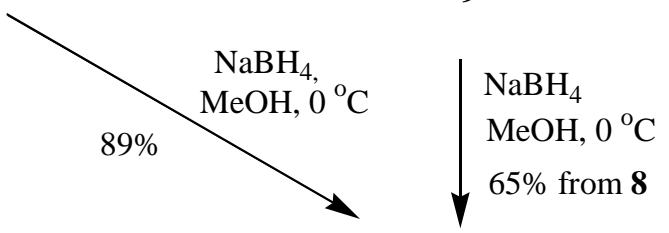
$\downarrow \mathrm{NaIO}_{4}, \mathrm{THF}^{-} \mathrm{H}_{2} \mathrm{O}$<smiles>CS(=O)(=O)OC1CC(C=O)C2OC(=O)C1O2</smiles>

13

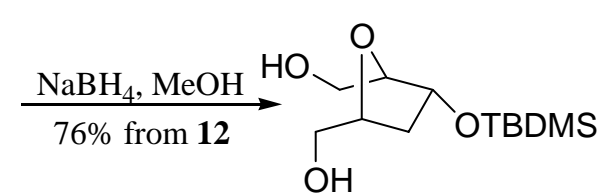

14

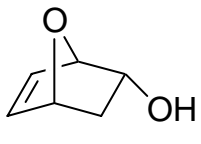

10

\section{Scheme 1}

Intermediate 14 was protected to its ditrityl derivative 15 with trityl chloride (82\%) which was desilylated using tetrabutylammonium fluoride (TBAF) in 85\% yield (Scheme 2). An attempt to invert the chirality at the $\mathrm{C}-3$ position of 17 using benzoic acid- $\mathrm{PPh}_{3}$-DEAD was not successful probably due to the bulky trityl groups. However, under similar conditions using $\mathrm{PPh}_{3}$ and $\mathrm{I}_{2}$ the iodide 20 with inverted configuration at the C-3 position was produced in $87 \%$ yield. ${ }^{1}$ Coupling the iodide $\mathbf{2 0}$ with sodium azide in dimethyl sulfoxide (DMSO) gave the desired azide 22 but in moderate yields (58\%). Elimination to produce an olefin byproduct $20^{1}$ in $16 \%$ yield was also observed. The catalytic reduction of the azide 22 was compromised by partial removal of the trityl protection to give 56\% yield of an amine 27 (Scheme 3). Thus, to avoid the problems derived from the trityl protection, the diol 14 was protected with $\mathrm{MOMCl}$ to give intermediate 16 which was desilylated to alcohol 18 in 79\% yield from 14 (Scheme 2). Treatment of alcohol 18 under Mitsunobu conditions and in the presence of benzoic acid afforded benzoate 23, which was debenzoylated with ammonia in methanol to give the inverted alcohol 24. As previously mentioned, this conversion with inversion of stereochemistry could not be achieved with the trityl counterpart 17. Alcohol 24 was mesylated to 25 (98\%) which was then treated with sodium azide in DMF to give azide $\mathbf{2 6}$ in $82 \%$ yield without the eliminative by-product. However, 
development of the pathway utilizing the MOM protecting group was done after the total synthesis was complete with the trityl protecting group in order to have a more efficient pathway for the synthesis of the key azido intermediate.

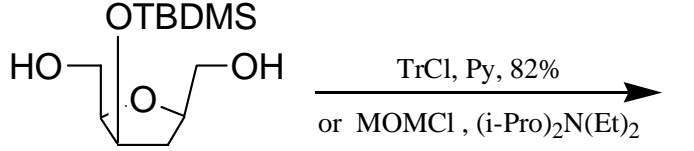

$( \pm) \quad 14$

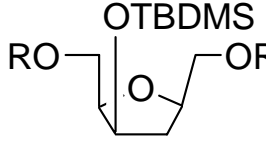

15: $\mathrm{R}=\mathrm{Tr}$

16: $\mathrm{R}=\mathrm{MOM}$

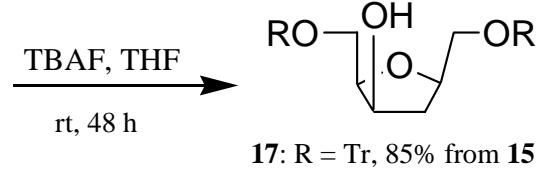

18: $\mathrm{R}=\mathrm{MOM}, 79 \%$ from 14

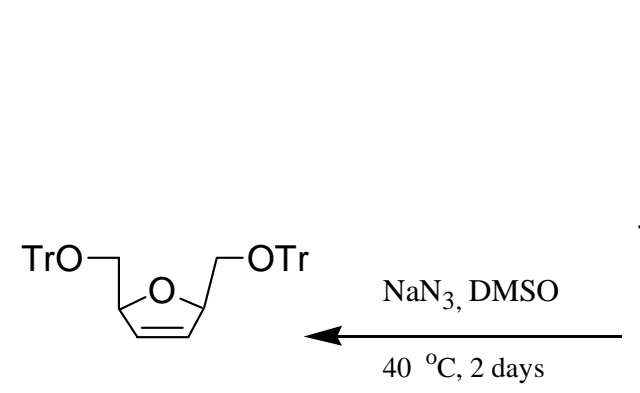

21: $16 \%$ from 20

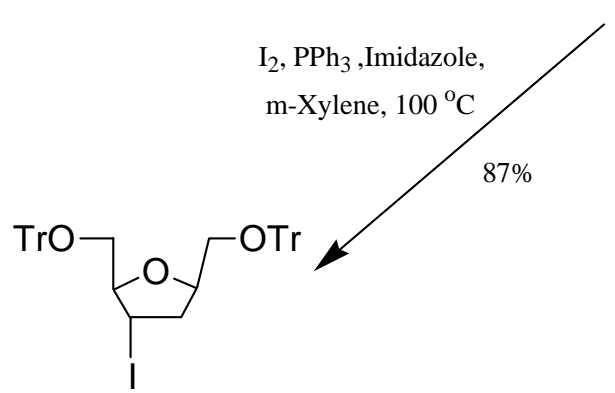

20

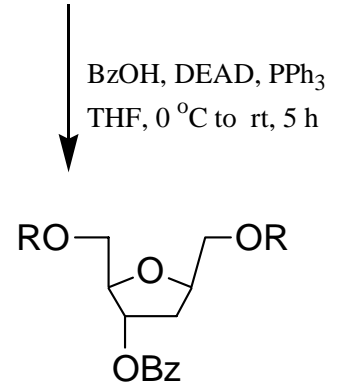

19: $\mathrm{R}=\mathrm{Tr}$, no reaction 23: $\mathrm{R}=\mathrm{MOM}$,

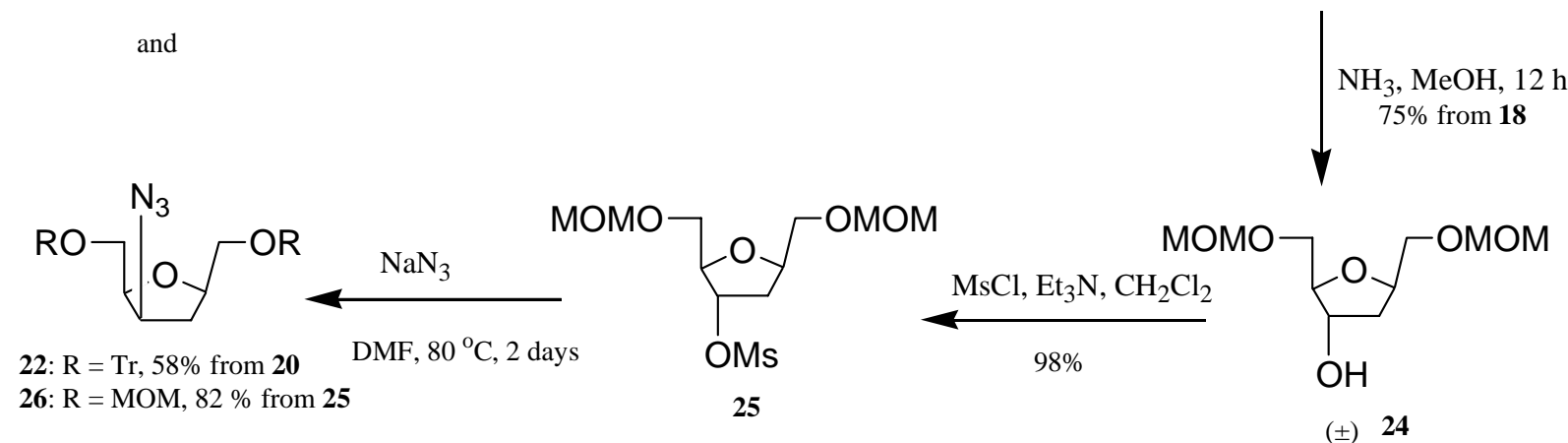

\section{Scheme 2}

Intermediate 27, prepared from the reduction of azido compound $( \pm) 22$ (Scheme 3), was coupled with 5-amino-4,6-dichloropyrimidine ${ }^{16}$ to give, in $68 \%$ yield, the pyrimidine intermediate $\mathbf{2 8}$ which, on treatment with triethyl orthoformate in the presence of $\mathrm{HCl}$, gave the 6-chloropurine derivative $\mathbf{2 9}$ with concomitant removal of the trityl groups (Scheme 3). 


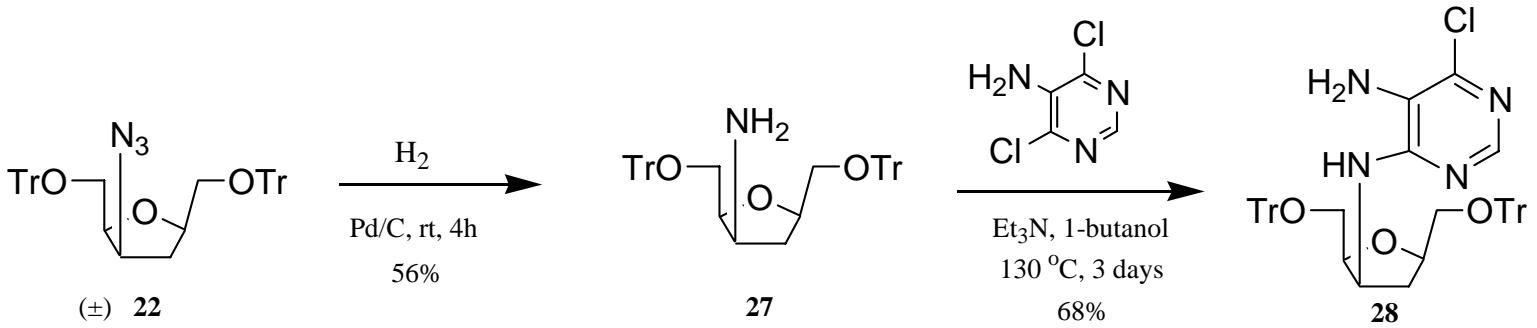

$$
\mathrm{MeO} \rightleftharpoons \text { NCO }\rfloor_{\substack{\mathrm{O} \\ \text { toluene, }-10{ }^{\circ} \mathrm{C} \\ \mathrm{h}}}
$$

$\mathrm{HC}(\mathrm{OEt})_{3}, \mathrm{HCl}$

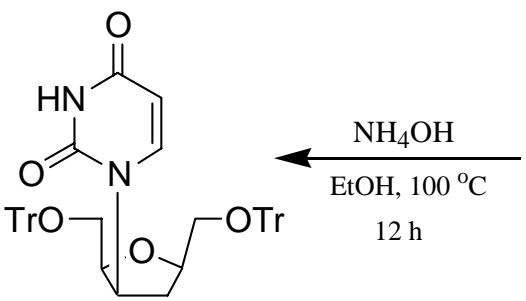

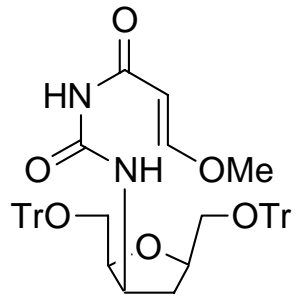

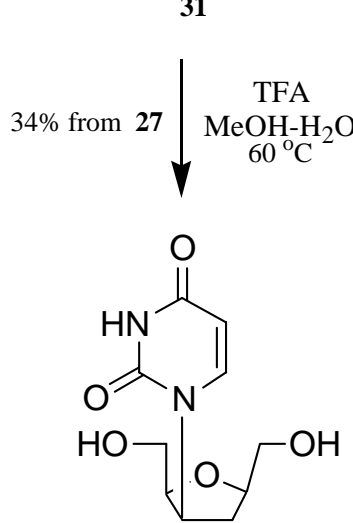

( \pm ) 4
30
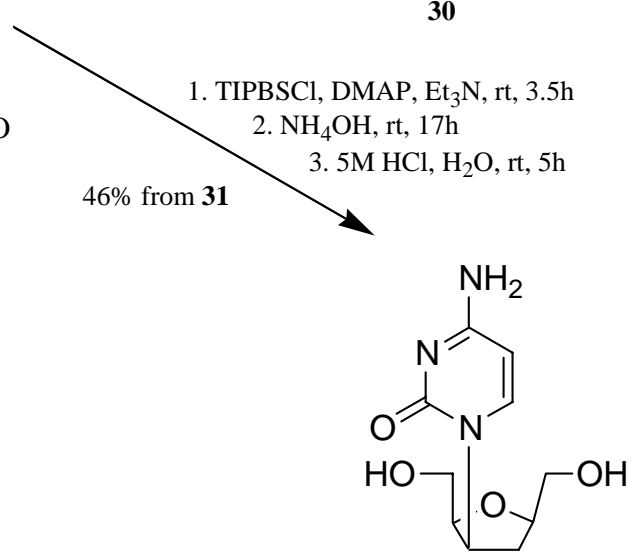

( \pm ) 5 $\mathrm{rt}, 4 \mathrm{~h}$

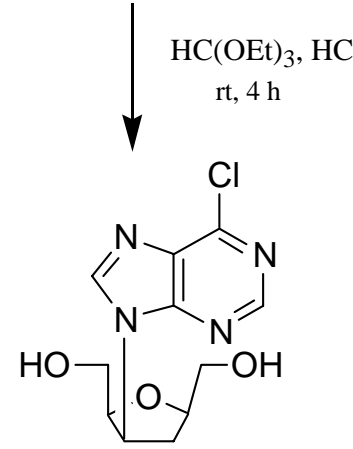

29

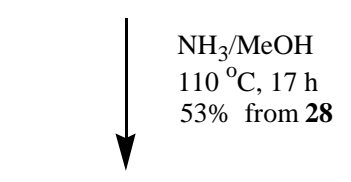<smiles>Nc1ncnc2c1ncn2CO</smiles>

$( \pm) 3$

\section{Scheme 3}

Ammonolysis with methanolic ammonia gave the desired adenosine analogue 3 in 53\% yield from 28. For the preparation of the uridine analogue, intermediate 27 was treated with 3methoxyacryloyl isocyanate, ${ }^{17}$ freshly prepared from 3-methoxyacryloyl chloride and silver cyanate to give an acryloylurea 30, which was then cyclized to the uracil analogue 31 on treatment with ammonium hydroxide at $100{ }^{\circ} \mathrm{C}$. Deprotection with trifluoroacetic acid gave the target uridine 4 (34\% yield from 27). The cytidine analogue 5 was obtained from the uridine 31 by sequential treatment with 2,4,6-triisopropylbenzenesulfonyl chloride and ammonium hydroxide ${ }^{18}$ followed by deprotection with dilute $\mathrm{HCl}$ in $46 \%$ yield. 
In summary, target compounds, 3, 4, and 5, were synthesized as racemates from the key intermediate, the tetrahydrofuran triol 14, which was obtained efficiently using a Diels-Alder pathway from basic starting compounds, furan (6) and 1-cyanovinylacetate (7). Antiviral studies of the target compounds are currently in progress.

\section{Experimental Section}

General Procedures. Melting points reported are uncorrected and were determined on an Electrothermal Engineering Ltd. melting point apparatus. Nuclear magnetic resonance spectra were recorded on Bruker Model AC300 and WM 360 systems. Ultraviolet spectra were recorded on a Varian Cary Model 3 spectrophotometer. Flash chromatography used 230-400 mesh silica gel. HPLC analyses were carried out on a Beckman-Coulter instrument with C-18 reversedphase columns.

( \pm )-2-endo/exo-Acetoxy-7-oxabicyclo[2.2.1]hept-5-en-2-exo/endo-carbonitrile (8). To a mixture of furan (6) (13.2 mL, $180.15 \mathrm{mmol}$ ) and 1-cyanovinylacetate (7) (5.0 g, $45.00 \mathrm{mmol}$ ) was added zinc iodide ( $7.20 \mathrm{~g}, 22.56 \mathrm{mmol})$. The resulting reaction mixture was stirred at room temperature in the dark for 4 days. The catalyst was removed by filtration and the filtrate was concentrated and purified by flash chromatography (hexanes: ethyl acetate $=5: 1$ ) to give a 3:1 mixture of compound 8 as a colorless liquid in $71 \%$ yield. ${ }^{1} \mathrm{H}$ NMR $\left(\mathrm{CDCl}_{3}\right)$ (major isomer) $\delta 6.64$ (dd, $1 \mathrm{H}$, $J=1.27,5.83 \mathrm{~Hz}$ ), 6.21 (dd, 1H, $J=1.54,5.83 \mathrm{~Hz}$ ), 5.58 (s, 1H), 5.13 (m, 1H), 2.73 (dd, $1 \mathrm{H}, J=$ 4.80, $12.70 \mathrm{~Hz}), 2.06$ (s, 3H), 1.73 (d, $1 \mathrm{H}, J=12.70 \mathrm{~Hz})$.

\section{( \pm )-7-Oxabicyclo[2.2.1]hept-5-en-2-endo-ol (10)}

Method 1. ${ }^{9,10}$ To a solution of compound 8 (3.6 g, $\left.20.09 \mathrm{mmol}\right)$ in tetrahydrofuran-water (1:1, $100 \mathrm{~mL}$ ) was added $1 \mathrm{~N}$ sodium hydroxide $(30 \mathrm{~mL})$ at $0{ }^{\circ} \mathrm{C}$. The resulting reaction mixture was stirred at $0{ }^{\circ} \mathrm{C}$ for $1 \mathrm{~h}$ and $37 \%$ formaldehyde $(120 \mathrm{~mL})$ was added to the reaction mixture, which was stirred at $0{ }^{\circ} \mathrm{C}$ for $10 \mathrm{~min}$ and extracted with chloroform ( 4 x $50 \mathrm{~mL}$ ). The organic layer was dried on sodium sulfate and concentrated under reduced pressure at $35{ }^{\circ} \mathrm{C}$. The resulting residue (compound 9) was dissolved in methanol $(20 \mathrm{~mL})$, to which was added sodium borohydride (1.6 g, $42.29 \mathrm{mmol}$ ) over $20 \mathrm{~min}$ at $0{ }^{\circ} \mathrm{C}$ (internal temperature), and the resulting reaction mixture was stirred for $1 \mathrm{~h}$ and concentrated under reduced pressure at $31{ }^{\circ} \mathrm{C}$. The residue obtained was purified by flash chromatography (hexanes: ethyl acetate $=2: 1$ ) to give compound 10 as colorless liquid (1.46 g, 65\%).

Method 2. To a solution of compound 8 (29 g, $162 \mathrm{mmol})$ in methanol $(600 \mathrm{~mL})$ at $0{ }^{\circ} \mathrm{C}$ (internal temperature) was added sodium borohydride (14 g, $370 \mathrm{mmol}$ ) over $20 \mathrm{~min}$. The resulting reaction mixture was stirred at room temperature overnight, neutralized under ice-bath 
temperatures with conc. $\mathrm{HCl}$, and concentrated. The resulting residue was purified by flash chromatography (hexanes:EtOAc $=1: 1)$ to give compound 10 (16 g, 89\%) as a colorless liquid. ${ }^{1} \mathrm{H}$ NMR $\left(\mathrm{CDCl}_{3}\right) \delta 6.64$ (dd, $1 \mathrm{H}, J=1.76,5.88 \mathrm{~Hz}$ ), 6.39 (dd, $\left.1 \mathrm{H}, J=1.29,5.87 \mathrm{~Hz}\right), 4.93$ (dd, $1 \mathrm{H}, J=1.54,6.49 \mathrm{~Hz}$ ), 4.89 (dd, $1 \mathrm{H}, J=1.16,4.51 \mathrm{~Hz}), 4.46$ (m, 1H), 2.30 (ddd, $1 \mathrm{H}, J=4.83$, 8.00, $11.90 \mathrm{~Hz}$ ), 1.25 (bs, $1 \mathrm{H}), 0.98$ (dd, $1 \mathrm{H}, J=2.33,11.91 \mathrm{~Hz}) ;{ }^{13} \mathrm{C} \mathrm{NMR}\left(\mathrm{CDCl}_{3}\right) \delta 138.48$, 131.83, 79.71, 79.40, 68.74, 35.87.

( \pm )-2-endo-tert-Butyldimethylsilyloxy-7-oxabicyclo[2.2.1]hept-5-ene (11). To a solution of a mixture of 10 (6.0 g, $53.51 \mathrm{mmol}$ ) and 4-N,N-dimethylpyridine (300 $\mathrm{mg}, 2.46 \mathrm{mmol}$ ) in anhydrous pyridine $(60 \mathrm{~mL})$ was added tert-butyldimethylsilyl chloride (16 g, $106.15 \mathrm{mmol})$ at 0 ${ }^{\circ} \mathrm{C}$. The resulting reaction mixture was stirred at room temperature for $24 \mathrm{~h}$. The reaction was quenched by ice water $(10 \mathrm{~mL})$. Then, the reaction mixture was diluted with ethyl acetate (500 $\mathrm{mL}$ ), washed with water (3 x $50 \mathrm{~mL})$, and brine (2 x $50 \mathrm{~mL})$. The organic layer was dried over sodium sulfate, concentrated, and separated by flash chromatography (hexanes: ethyl acetate = 40:1) to give compound 11 as a colorless liquid (10g, 83\%). ${ }^{1} \mathrm{H}$ NMR $\left(\mathrm{CDCl}_{3}\right) \delta 6.48$ (dd, $1 \mathrm{H}, J$ $=1.70,5.88 \mathrm{~Hz}), 6.26(\mathrm{dd}, 1 \mathrm{H}, J=1.50,5.87 \mathrm{~Hz}), 4.88(\mathrm{dd}, J=1.64,4.81 \mathrm{~Hz}), 4.76(\mathrm{dd}, 1 \mathrm{H}, J=$ 1.50, $4.44 \mathrm{~Hz}$ ), 4.40 (m, 1H), 2.14 (m, 1H), 0.94 (dd, 1H, $J=2.32,11.33 \mathrm{~Hz}$ ), 0.86 (s, 9H), 0.06 (s, 3H), 0.04 (s, 3H); ${ }^{13} \mathrm{C} \mathrm{NMR}\left(\mathrm{CDCl}_{3}\right) \delta 82.41,78.49,73.63,64.85,62.70,37.28,25.83,18.08$, $-4.63,-5.08$.

( \pm )-(2R/S, 3R/S, 5R/S)-3-tert-Butyldimethylsilyloxy-2,5-di(hydroxymethyl)tetrahydrofuran (14). To a solution of compound $11(1.37 \mathrm{~g}, 6.05 \mathrm{mmol})$ in acetone (20 mL) containing $N$-methyl morpholine $N$-oxide (610 mg, $5.21 \mathrm{mmol}$ ) was added osmium tetroxide (48 $\mathrm{mg}, 0.19 \mathrm{mmol}$ ) under ice bath temperature. The solution was stirred at room temperature for $14 \mathrm{~h}$. Sodium hydrosulfite (1.36 g, $7.81 \mathrm{mmol}$ ) was added to the reaction mixture, which was stirred at room temperature for $30 \mathrm{~min}$ and concentrated under reduced pressure. The residue obtained was dissolved in brine $(100 \mathrm{~mL})$ and extracted with chloroform $(5 \times 50 \mathrm{~mL})$. The organic layer was dried with sodium sulfate, concentrated, and purified by flash chromatography (hexanes: ethyl acetate $=1: 2)$ to give compound $12(1.36 \mathrm{~g}, 86 \%$ ) as a syrup. To a solution of compound 12 (900 $\mathrm{mg}, 3.03 \mathrm{mmol})$ in tetrahydrofuran-water $(4: 1,50 \mathrm{~mL})$ was added sodium periodate $(1.98 \mathrm{~g}, 9.26$ mmol) in portions at $0{ }^{\circ} \mathrm{C}$. The resulting reaction mixture was stirred at room temperature for 1.5 h, then diluted with brine (200 mL), and extracted with chloroform (5 x $100 \mathrm{~mL}$ ). The combined organic layer was dried on sodium sulfate and concentrated. The residue (compound 13) was dissolved in tetrahydrofuran $(200 \mathrm{~mL})$ and cooled to $-10{ }^{\circ} \mathrm{C}$, to which sodium borohydride (804 $\mathrm{mg}, 21.25 \mathrm{mmol})$ in methanol $(10 \mathrm{~mL})$ was added over $10 \mathrm{~min}$. The resulting reaction was stirred at room temperature for $30 \mathrm{~min}$ and concentrated. The resulting residue was purified by flash chromatography (chloroform:methanol = 30:1) to give compound 14 (688 mg, 76\% from 12) as colorless syrup. ${ }^{1} \mathrm{H}$ NMR $\left(\mathrm{CDCl}_{3}\right) \delta 4.44(\mathrm{~m}, 1 \mathrm{H}), 4.09(\mathrm{~m}, 1 \mathrm{H}), 3.89(\mathrm{~m}, 2 \mathrm{H}), 3.79-3.71(\mathrm{~m}$, 
3H), 3.58 (m, 1H), 3.27 (bs, 1H), 3.00 (bs, 1H), 2.18 (m, 1H), 1.80 (m 1H), 0.87 (s, 9H), 0.07 (s, $6 \mathrm{H}) ;{ }^{13} \mathrm{C} \mathrm{NMR}\left(\mathrm{CDCl}_{3}\right) \delta 82.49,78.49,73.65,64.85,62.70,37.28,25.83,18.08,-4.63,-5.08$.

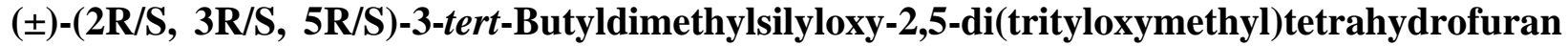
(15). To a solution of compound 14 (910 mg, $3.47 \mathrm{mmol})$ in anhydrous pyridine (20 mL) was added trityl chloride (3.42 g, $12.27 \mathrm{mmol}$ ) at room temperature. The resulting reaction mixture was stirred for $18 \mathrm{~h}$. Additional trityl chloride (3.00g, $10.76 \mathrm{mmol}$ ) was added and the reaction was continued for $18 \mathrm{~h}$ and quenched by adding cold water $(5 \mathrm{~mL})$. The reaction mixture was diluted by ethyl acetate (500 mL), and washed with water (2 x $100 \mathrm{~mL})$ and brine (2 x $100 \mathrm{~mL})$. After concentration, the residue was separated by flash chromatography (hexanes: EtOAc = 40:1) to give compound 15 as white solid (2.12 g, 82\%). ${ }^{1} \mathrm{H} \mathrm{NMR}\left(\mathrm{CDCl}_{3}\right) \delta$ 7.48-7.15 (m, 30H), 4.27-4.24 (m, 3H), 4.08 (m, 1H), 3.45 (m, 2H), 3.13 (dd, 1H, $J=4.33,9.84 \mathrm{~Hz}$ ), 2.83 (dd, 1H, $J$ = 4.90, $9.14 \mathrm{~Hz}), 2.19(\mathrm{~m}, 1 \mathrm{H}), 1.57(\mathrm{~m}, 1 \mathrm{H}), 0.54(\mathrm{~s}, 9 \mathrm{H}),-0.18(\mathrm{~s}, 3 \mathrm{H}),-0.26(\mathrm{~s}, 3 \mathrm{H}) ;{ }^{13} \mathrm{C} \mathrm{NMR}$ $\left(\mathrm{CDCl}_{3}\right) \delta 144.29,144.25,128.87,128.85,127.76,127.69,126.83,126.77,86.82,86.38,83.65$, 72.37, 67.87, 64.34, 38.60, 25.60, 17.71, -4.82, -5.38.

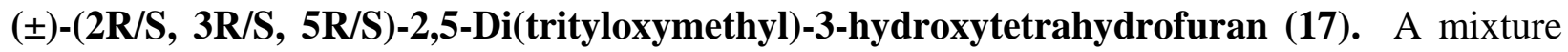
of compound 15 (2.20 g, $2.94 \mathrm{mmol}$ ) and tetrabutylammonium fluoride (1.54 g, $5.89 \mathrm{mmol})$ in tetrahydrofuran (125 mL) was stirred at room temperature for $48 \mathrm{~h}$. After concentration, the resulting residue was purified by flash chromatography (hexanes:EtOAc $=10: 1$ ) to give compound 17 as white foam (1.58 g, 85\%). ${ }^{1} \mathrm{H}$ NMR $\left(\mathrm{CDCl}_{3}\right) \delta$ 7.91-7.20 (m, 30H), $4.25(\mathrm{~m}$, $1 \mathrm{H}), 4.16$ (m, 1H), 3.93 (m, 1H), 3.50 (d, 2H, $J=5.53 \mathrm{~Hz}$ ), 3.45 (dd, 1H, $J=3.19,10.11 \mathrm{~Hz}$ ), 3.26 (d, 1H, $8.65 \mathrm{~Hz}$ ), 3.07 (dd, 1H, $J=3.84,10.07 \mathrm{~Hz}$ ), 2.27 (ddd, 1H, $J=5.71$, 9.47, 13.87 $\mathrm{Hz}), 1.73$ (ddd, $1 \mathrm{H}, J=1.32,4.24,13.79 \mathrm{~Hz}) ;{ }^{13} \mathrm{C} \mathrm{NMR}\left(\mathrm{CDCl}_{3}\right) \delta 143.94,143.49,128.87$, 128.83, 127.93, 127.90, 127.09, 127.00, 87.42, 86.96, 82.51, 82.41, 76.94, 72.29, 66.21, 62.91, 37.56.

( \pm )-(2R/S, 3S/R, 4R/S)-2,5-Ditrityloxymethyl-3-iodotetrahydrofuran (20). A mixture of compound 17 (2.73 g, $4.31 \mathrm{mmol}$ ), triphenylphosphine (1.70 g, $6.47 \mathrm{mmol})$, and imidazole (880 $\mathrm{mg}, 12.93 \mathrm{mmol})$ was dissolved in anhydrous m-xylene $(100 \mathrm{~mL})$ at $80{ }^{\circ} \mathrm{C}$. Iodine $(1.64 \mathrm{~g}, 6.47$ mmol) was added slowly at $80{ }^{\circ} \mathrm{C}$. The resulting reaction mixture was stirred at $100{ }^{\circ} \mathrm{C}$ for $1 \mathrm{~h}$. Sodium hydrosulfite $(2.25 \mathrm{~g}, 12.93 \mathrm{mmol})$ was added at room temperature to the reaction mixture, which was stirred for $1 \mathrm{~h}$ and concentrated. The resulting residue was purified by flash chromatography (hexanes:EtOAc $=10: 1)$ to give compound 20 as white solid $(2.78 \mathrm{~g}, 87 \%) .{ }^{1} \mathrm{H}$ NMR $\left(\mathrm{CDCl}_{3}\right) \delta$ 7.43-7.18 (m, 30H), 4.38-4.33 (m, 2H), 4.24-4.20 (m, 1H), 3.26-3.14 (m, 4H), 2.32-2.28 (m, 2H); ${ }^{13} \mathrm{C} \mathrm{NMR}\left(\mathrm{CDCl}_{3}\right) \delta 143.89,143.79,128.69,127.82,127.79,126.16,88.13$, 86.61, 77.91, 65.42, 63.59, 40.64, 20.42; HRFABMS calcd for $\mathrm{C}_{44} \mathrm{H}_{39} \mathrm{~N}_{3} \mathrm{O}_{3} \mathrm{NaI}$ 765.1841, found $765.1863(\mathrm{M}+\mathrm{Na})^{+}$.

( \pm )-(2R/S, 3R/S, 5R/S)-2,5-Di[(O-methoxymethyl)methyl]-3-hydroxy-tetrahydrofuran (18). To a solution of compound $14(1.30 \mathrm{~g}, 4.95 \mathrm{mmol})$ in anhydrous methylene chloride (20 $\mathrm{mL})$ 
containing diisopropylmethylamine $(3.0 \mathrm{~mL})$ was added methoxymethyl chloride $(1.50 \mathrm{~mL}$, $19.75 \mathrm{mmol}$ ) slowly at $0{ }^{\circ} \mathrm{C}$. The resulting reaction mixture was stirred at $0^{\circ} \mathrm{C}$ for $1 \mathrm{~h}$, to which cold water $(15 \mathrm{~mL})$ was added, and extracted with chloroform (3 x $15 \mathrm{~mL})$. The combined organic layer was dried, concentrated, and purified by silica gel column chromatography (hexanes: $\mathrm{EtOAc}=3: 1$ ) to give a residue (compound 16). A mixture of $\mathbf{1 6}$ and TBAF (2.59 g, $9.90 \mathrm{mmol})$ in tetrahydrofuran $(50 \mathrm{~mL})$ was stirred at room temperature for $24 \mathrm{~h}$, concentrated, and purified by flash chromatography (hexanes: EtOAc $=1: 1$ ) to give compound $\mathbf{1 8}$ as a syrup (923 mg, 79\%). ${ }^{1} \mathrm{H}$ NMR $\left(\mathrm{CDCl}_{3}\right) \delta 4.67$ (s, 2H), 4.66 (s, 2H), 4.29 (m, 1H), 4.19 (m, 1H), 3.90 (m, 1H), 3.79-3.73 (m, 2H), 3.54 (dd, 1H, $J=2.70,10.56 \mathrm{~Hz}$ ), 3.39 (s, 3H), 3.38 (s, 3H), 2.37 (m, 1H), 1.92 (dd, $1 \mathrm{H}, J=3.32,13.95 \mathrm{~Hz}) ; 3.52$ (d, $1 \mathrm{H}, J=10.20 \mathrm{~Hz}) ;{ }^{13} \mathrm{C}$ NMR $\left(\mathrm{CDCl}_{3}\right) \delta$ 96.80, 96.50, 82.68, 76.65, 71.72, 69.32, 66.73, 55.60, 55.29, 37.13.

( \pm )-(2R/S, 3S/R, 5R/S)-2,5-Di[(O-methoxymethyl)methyl]-3-hydroxytetrahydrofuran (24). To a solution of compound 18 (795 mg, $3.36 \mathrm{mmol})$ in anhydrous tetrahydrofuran (20 $\mathrm{mL})$ containing triphenylphosphine (1.76 g, $10.10 \mathrm{mmol}$ ) and benzoic acid (1.23 g, $10.07 \mathrm{mmol}$ ) was added DEAD (2.81 g, $16.13 \mathrm{mmol})$ in tetrahydrofuran $(5 \mathrm{~mL})$ through a dropping funnel over 10 min. The resulting reaction mixture was stirred at room temperature for $4 \mathrm{~h}$, concentrated, and purified by flash chromatography (hexanes: EtOAc $=4: 1$ ) to give a residue $(23)$, which was dissolved in methanolic ammonia $(10 \mathrm{~mL})$, heated at $90{ }^{\circ} \mathrm{C}$ for $12 \mathrm{~h}$, and concentrated. The residue obtained was purified by flash chromatography (hexanes: EtOAc $=1: 1$ ) to give compound 24 as syrup (600 mg. 75\%). ${ }^{1} \mathrm{H}$ NMR $\left(\mathrm{CDCl}_{3}\right) \delta 4.65$ (s, 2H), $4.64(\mathrm{~s}, 2 \mathrm{H}), 4.37$ (m, $1 \mathrm{H}), 4.30$ (m, 1H), 3.95 (m, 1H), 3.67-3.62 (m, 2H), 3.56-3.51 (m, 2H), 3.37 (2s, 6H), 1.97-1.93 $(\mathrm{m}, 2 \mathrm{H}) ;{ }^{13} \mathrm{C} \mathrm{NMR}\left(\mathrm{CDCl}_{3}\right) \delta 96.77,96.60,85.36,77.39,74.08,69.79,68.08,55.32,55.23$, 37.10 .

( \pm )-(2R/S, 3S/R, 5R/S)-2,5-Di[(O-methoxymethyl)methyl]-3-O-methanesulfonyltetrahydrofuran (25). To a solution of compound 24 (600 mg, $2.54 \mathrm{mmol})$ and triethylamine (3 $\mathrm{mL})$ in anhydrous methylene chloride $(40 \mathrm{~mL})$ was added methanesulfonyl chloride $(0.80 \mathrm{~mL}, 10.34$ mmol) slowly at ${ }^{\circ} \mathrm{C}$ for $30 \mathrm{~min}$, and diluted with cold water $(100 \mathrm{~mL})$ and extracted with chloroform ( 2 x $100 \mathrm{~mL})$. The organic layer was washed with brine (80 mL), dried, concentrated, and purified by flash chromatography (hexanes: EtOAc $=1: 1$ ) to give compound 25 as a syrup (780 mg, 98\%). ${ }^{1} \mathrm{H}$ NMR $\left(\mathrm{CDCl}_{3}\right) \delta 5.17$ (m, 1H), 4.66-4.63 (m, 4H), 4.35 (m, 1H), 4.22 (m, 1H), 3.68 (m, 2H), 3.55 (dd, 2H, $J=5.71,10.69 \mathrm{~Hz}$ ), 3.36 (2s, 6H), 3.06 (s, 3H), 2.25 (ddd, 1H, $J=1.58,5.47,13.92 \mathrm{~Hz}$ ), 2.07 (ddd, $1 \mathrm{H}, J=6.17,10.26,13.93 \mathrm{~Hz}$ ).

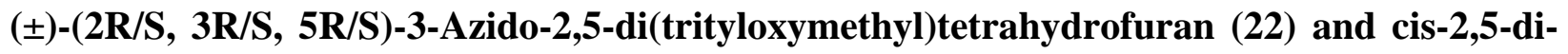
(trityloxymethyl)-2,5-dihydrofuran (21). A mixture of compound 20 (4.0 g, $5.39 \mathrm{mmol}$ ) and sodium azide (1.57 g, $24.15 \mathrm{mmol})$ in anhydrous dimethyl sulfoxide (150 mL) was stirred at $40^{\circ} \mathrm{C}$ for $48 \mathrm{~h}$, diluted with ethyl acetate $(500 \mathrm{~mL})$, and washed with water ( $\left.3 \mathrm{x} 50 \mathrm{~mL}\right)$. The organic layer was concentrated in vacuo and the residue was separated by flash chromatography 
(hexanes: EtOAc = 30:1) to give compound 22 as a white solid (2.06 g, 58\%) and compound 21 as a glassy solid (530 mg, 16\%). Compound 22: ${ }^{1} \mathrm{H}$ NMR $\left(\mathrm{CDCl}_{3}\right) \delta$ 7.50-7.19 (m, 30H), $4.12(\mathrm{~m}$ 2H), 3.98 (dd, 1H, $J=6.05,10.40 \mathrm{~Hz}$ ), 3.45 (dd, $1 \mathrm{H}, J=5.62,9.50 \mathrm{~Hz}$ ), 3.28 (dd, $1 \mathrm{H}, J=6.16$, $9.40 \mathrm{~Hz}$ ), 3.22 (dd, 1H, $J=6.80,9.46 \mathrm{~Hz}$ ), 3.00 (dd, 1H, $J=$ 5.69, $9.36 \mathrm{~Hz}$ ), 2.33 (m, 1H), 1.87 (ddd, $1 \mathrm{H}, J=2.28,5.52,13.93 \mathrm{~Hz}) ;{ }^{13} \mathrm{C}$ NMR $\left(\mathrm{CDCl}_{3}\right) \delta 143.97,143.89,128.72,127.80$, 127.76, 127.00, 126.92, 86.99, 86.57, 81.50, 66.15, 62.60, 34.78. Compound 21: $\delta$ 7.40-7.15 (m, $30 \mathrm{H}$ ), 5.87 (s, 2H), 4.95 (m, 2H), 3.22 (dd, 2H, $J=4.88,9.36 \mathrm{~Hz}$ ), 3.06 (dd, 2H, $J=4.56,9.36$ $\mathrm{Hz}) ;{ }^{13} \mathrm{C}$ NMR $\left(\mathrm{CDCl}_{3}\right) \delta 144.04,128.89,128.73,127.71,126.87,86.51,85.73,67.54$; HRFABMS calcd for $\mathrm{C}_{44} \mathrm{H}_{39} \mathrm{~N}_{3} \mathrm{O}_{2} \mathrm{Na} 680.2889$, found $680.2903(\mathrm{M}+\mathrm{Na})^{+}$.

( \pm )-(2R/S, 3R/S, 5R/S)-3-Azido-2,5-di[(O-methoxymethyl)methyl]-tetrahydrofuran (26). A mixture of compound 25 (1.0 g, $3.18 \mathrm{mmol})$ and sodium azide $(1.1 \mathrm{~g}, 16.92 \mathrm{mmol})$ in anhydrous DMF (30 mL) was heated at $80{ }^{\circ} \mathrm{C}$ for 2 days, concentrated in vacuo, and purified by flash chromatography (chloroform: methanol $=3: 1)$ to give compound 26 (681 mg. 82\%) as a syrup. ${ }^{1} \mathrm{H}$ NMR $\left(\mathrm{CDCl}_{3}\right) \delta 4.68(2 \mathrm{~s}, 4 \mathrm{H}), 4.21-4.15(\mathrm{~m}, 2 \mathrm{H}), 4.02(\mathrm{dd}, 1 \mathrm{H}, \mathrm{J}=5.89,10.57 \mathrm{~Hz}), 3.79-$ $3.71(\mathrm{~m}, 2 \mathrm{H}), 3.69-3.60$ (m, 2H), 3.40 (s, 3H), 3.39 (s, 3H), $2.43(\mathrm{~m}, 1 \mathrm{H}), 1.96(\mathrm{~m}, 1 \mathrm{H}) ;{ }^{13} \mathrm{C}$ $\operatorname{NMR}\left(\mathrm{CDCl}_{3}\right) \delta 96.89,96.70,80.80,77.06,69.63,66.43,62.18,55.42,55.34,34.33$.

( \pm )-(2'R/S, 3'R/S, 5'R/S)-5-Amino-4-chloro-6-[[2',5'-di(trityloxymethyl)tetrahydrofuran3'-yl]amino]pyrimidine (28). A mixture of compound 22 (1.40 g, $2.13 \mathrm{mmol})$ and $10 \% \mathrm{Pd} / \mathrm{C}$ (235 mg) in ethanol $(120 \mathrm{~mL}$ ) was stirred in a Parr apparatus with $30 \mathrm{psi}$ of hydrogen for $4 \mathrm{~h}$ and worked up. The residue obtained was purified by flash chromatography (chloroform: methanol $=$ 3:1) to give compound 27 as a syrup (754 mg, 56\%). A mixture of compound 27 (500 mg, 0.79 mmol) and triethylamine $(2 \mathrm{~mL})$ in 1-butanol $(10 \mathrm{~mL})$ was refluxed at $130{ }^{\circ} \mathrm{C}$ for 3 days and concentrated under reduced pressure. The residue was purified by flash chromatography (hexanes: ethylacetate $=10: 1)$ to give compound 28 as syrup (408 mg, 68\%). ${ }^{1} \mathrm{H}$ NMR $\left(\mathrm{CDCl}_{3}\right) \delta$ 7.91 (s, 1H), 7.47-7.19 (m, 30H), 6.06 (d, 1H, J = $7.36 \mathrm{~Hz}), 4.82$ (m, 1H), 4.23 (m, 1H), 4.17 (m, 1H), 3.50 (dd, $1 \mathrm{H}, J=4.99,10.32 \mathrm{~Hz}$ ), 3.37 (dd, $1 \mathrm{H}, J=3.96,9.85 \mathrm{~Hz}$ ), 3.11 (dd, $1 \mathrm{H}, J=2.90$, $10.32 \mathrm{~Hz}$ ), 2.56 (m, 1H), 1.87 (m, 1H), 1.57 (bs, 2H).

( \pm )-(2'R/S, 3'R/S, 5'R/S)-3'-(Adenin-9-yl)-2',5'- di(hydroxymethyl)tetrahydrofuran (3). To a solution of compound $28(300 \mathrm{mg}, 0.40 \mathrm{mmol})$ in triethyl orthoformate $(5 \mathrm{~mL})$ was added conc. $\mathrm{HCl}(40 \mu \mathrm{L})$. The resulting reaction mixture was stirred at room temperature for $4 \mathrm{~h}$ and poured into sat. aqueous $\mathrm{NaHCO}_{3}(5 \mathrm{~mL})$. After concentration, the residue was purified by flash chromatography (chloroform: methanol $=30: 1$ ) to give compound 29 as a white solid. Compound 29 was dissolved in methanol $(70 \mathrm{~mL})$, bubbled with ammonia at $-10{ }^{\circ} \mathrm{C}$ for $10 \mathrm{~min}$, transferred to a steel bomb which was sealed and heated at $110^{\circ} \mathrm{C}$ for $17 \mathrm{~h}$. After concentration, the residue was purified by flash chromatography (pre-saturated with triethylamine) (chloroform: methanol $=10: 1$ ) to give compound 3 as a white solid (56 mg, 53\%). $\mathrm{mp} 223{ }^{\circ} \mathrm{C}$; UV $\lambda_{\text {max }} 260$ nm (MeOH, \& 11 277); ${ }^{1} \mathrm{H}$ NMR $\left(\mathrm{D}_{2} \mathrm{O}\right) \delta 8.37$ (s, $\left.1 \mathrm{H}\right), 8.21$ (s, $\left.1 \mathrm{H}\right), 5.37$ (m, 1H), $4.25(\mathrm{~m}, 2 \mathrm{H})$, 
4.04 (dd, $1 \mathrm{H}, J=2.15,11.81 \mathrm{~Hz}$ ), 3.86 (dd, $1 \mathrm{H}, J=4.43,12.62 \mathrm{~Hz}$ ), 3.33 (dd, $1 \mathrm{H}, J=3.67$, $12.05 \mathrm{~Hz}$ ), 3.17 (dd, $1 \mathrm{H}, J=6.8,12.07 \mathrm{~Hz}), 2.85(\mathrm{~m}, 1 \mathrm{H}), 2.37(\mathrm{~m}, 1 \mathrm{H}) ;{ }^{13} \mathrm{C}$ NMR $\left(\mathrm{D}_{2} \mathrm{O}+\right.$ DMSO- $\left.d_{6}\right) \delta 157.20,154.10,150.69,142.60,119.63,82.80,80.36,62.80,61.24,56.80,34.69$; HRFABMS calcd for $\mathrm{C}_{11} \mathrm{H}_{16} \mathrm{~N}_{5} \mathrm{O}_{3} 266.1253$, found $266.1254(\mathrm{M}+\mathrm{H})^{+}$.

( \pm )-(2'R/S, 3'R/S, 5'R/S)-2',5'-Di(hydroxymethyl)-3'-(uracil-1-yl)tetrahydrofuran (4). To a suspension of dried silver cyanate $(0.26 \mathrm{~g}, 1.75 \mathrm{mmol})$ in anhydrous toluene $(6 \mathrm{~mL})$ was added freshly prepared $\beta$-methoxyacryloyl chloride $(0.12 \mathrm{~g}, 0.99 \mathrm{mmol})$ at room temperature. The reaction mixture was heated under reflux at $150{ }^{\circ} \mathrm{C}$ for $30 \mathrm{~min}$ and cooled to room temperature. The supernatant was transferred to a solution of compound 27 (100 mg. $0.16 \mathrm{mmol}$ ) in anhydrous toluene ( $3 \mathrm{~mL}$ ) at $-10{ }^{\circ} \mathrm{C}$ over $10 \mathrm{~min}$. The resulting reaction mixture was stirred at $10{ }^{\circ} \mathrm{C}$ for $1.5 \mathrm{~h}$, poured into cold $\mathrm{NaHCO}_{3}$ solution, and extracted with chloroform (3 x $10 \mathrm{~mL}$ ). The organic layer was concentrated, dissolved in ethyl alcohol $(6 \mathrm{~mL})$ containing ammonium hydroxide $(1 \mathrm{~mL})$, and heated in a sealed steel bomb at $100{ }^{\circ} \mathrm{C}$ for $12 \mathrm{~h}$. After concentration, the residue was purified by flash chromatography (hexanes: ethyl acetate $=3: 1$ to 2:1) to give compound 31, which was dissolved in methanol $(3 \mathrm{~mL})$ and water $(5 \mathrm{~mL})$ containing trifluoroacetic acid $(1 \mathrm{~mL})$ and stirred at $60{ }^{\circ} \mathrm{C}$ for $5 \mathrm{~h}$. After concentration and coevaporation with toluene, the resulting residue was purified by flash chromatography (chloroform: methanol $=10: 1)$ to give compound 4 as a hygroscopic solid (13 mg, 35\%). UV $\lambda_{\max } 260 \mathrm{~nm}(\mathrm{MeOH}, \varepsilon 10$ 890); ${ }^{1} \mathrm{H}$ NMR $\left(\mathrm{D}_{2} \mathrm{O}\right) \delta 7.89$ (d, $\left.1 \mathrm{H}, J=8.08 \mathrm{~Hz}\right), 5.87$ (d, $\left.1 \mathrm{H}, J=8.06 \mathrm{~Hz}\right), 5.35$ (m, 1H), 4.18$4.13(\mathrm{~m}, 2 \mathrm{H}), 3.99(\mathrm{~m}, 1 \mathrm{H}), 3.79(\mathrm{~m}, 1 \mathrm{H}), 3.66-3.60(\mathrm{~m}, 2 \mathrm{H}), 2.64(\mathrm{~m}, 1 \mathrm{H}), 2.07(\mathrm{~m}, 1 \mathrm{H}) ;{ }^{13} \mathrm{C}$ NMR $\left(\mathrm{D}_{2} \mathrm{O}+\mathrm{DMSO}_{-} d_{6}\right) \delta 167.70,153.95,146.06,103.25,82.54,80.14,63.30,61.21,57.71$, 33.59; HRFABMS calcd for $\mathrm{C}_{10} \mathrm{H}_{15} \mathrm{~N}_{2} \mathrm{O}_{5} 243.0980$, found $243.0987(\mathrm{M}+\mathrm{H})^{+}$.

( \pm )-(2'R/S, 3'R/S, 5'R/S)-2',5'-Di(hydroxymethyl)-3'-(cytosin-1-yl)tetrahydrofuran (5). To a solution of compound $31(131 \mathrm{mg}, 0.18 \mathrm{mmol})$ in anhydrous acetonitrile $(10 \mathrm{~mL})$ containing $\mathrm{Et}_{3} \mathrm{~N}(2 \mathrm{~mL})$ and DMAP (89 $\mathrm{mg}, 0.73 \mathrm{mmol}$ ) was added 2,4,6-triisopropyl-benzenesulfonyl chloride (220 mg, $0.72 \mathrm{mmol}$ ) in portions at $0{ }^{\circ} \mathrm{C}$. The resulting reaction mixture was stirred at room temperature for $3.5 \mathrm{~h}$. Then, aqueous ammonia $(29 \%, 7 \mathrm{~mL})$ was added to the reaction mixture, which was stirred for $17 \mathrm{~h}$, concentrated, and purified by flash chromatography (chloroform: methanol $=30: 1$ to 10:1). The cytidine derivative thus obtained was dissolved in methanol $(5 \mathrm{~mL})$ containing $5 \mathrm{M} \mathrm{HCl}(1 \mathrm{~mL})$ and stirred at room temperature for $5 \mathrm{~h}$, concentrated, neutralized with potassium carbonate powder, and purified by flash chromatography (chloroform: methanol $=10: 1$ to $5: 1)$ to give compound 5 (20 mg, 86\%) as a white solid. mp 230-233 ${ }^{\circ} \mathrm{C}$; UV $\lambda_{\max } 275 \mathrm{~nm}(\mathrm{MeOH}, \varepsilon 10,110) ;{ }^{1} \mathrm{H}$ NMR $\left(\mathrm{D}_{2} \mathrm{O}\right) \delta 7.78(\mathrm{~d}, 1 \mathrm{H}$, $J=7.54 \mathrm{~Hz}$ ), 5.99 (d, 1H, $J=7.50 \mathrm{~Hz}$ ), 5.33-4.75 (m, 1H), 4.18-4.14 (m, 1H), 4.09 (m, 1H), 3.91 (dd, $1 \mathrm{H}, \mathrm{J}=2.91,12.53 \mathrm{~Hz}$ ), 3.74 (dd, $1 \mathrm{H}, J=4.80,12.53 \mathrm{~Hz}$ ), 3.53 (dd, $1 \mathrm{H}, J=3.80,12.26$ $\mathrm{Hz}$ ), 3.38 (dd, $1 \mathrm{H}, J=6.71,12.26 \mathrm{~Hz}), 2.53(\mathrm{~m}, 1 \mathrm{H}), 2.03(\mathrm{~m}, 1 \mathrm{H}) ;{ }^{13} \mathrm{C} \mathrm{NMR}\left(\mathrm{D}_{2} \mathrm{O}+\mathrm{CD}_{3} \mathrm{OD}\right) \delta$ 
166.10, 158.72, 144.27, 96.01, 81.35, 78.72, 62.19, 60.23, 57.08, 32.30; HRFABMS calcd for $\mathrm{C}_{10} \mathrm{H}_{16} \mathrm{~N}_{3} \mathrm{O}_{4} 242.1140$, found $242.1130(\mathrm{M}+\mathrm{H})^{+}$.

\section{Acknowledgements}

The project described was supported by Grant Number AI 32851 from the National Institutes of Health. Its contents are solely the responsibility of the authors and do not necessarily represent the official views of the NIH.

\section{References}

1. (a) Nair, V.; Jahnke, T. S. Antimicrob. Agents Chemother. 1995, 39, 1017. (b) Nair, V. in Recent Advances in Nucleosides: Chemistry and Chemotherapy; Chu, C. K., Ed., Elsevier Science: Amsterdam, Netherlands, 2002, 149.

2. (a) Nair, V.; Nuesca, Z. M. J. Am. Chem. Soc. 1992, 114, 7951. (b) Bolon, P. S.; Sells, T. B.; Nuesca, Z. M.; Purdy, D. F.; Nair, V. Tetrahedron 1994, 50, 7747. (c) Bera, S.; Nair, V. Helv. Chim. Acta 2000, 831398.

3. Mickle, T.; Nair, V. Antimicrob. Agents Chemother 2000, 44, 2939.

4. Bera, S.; Nair, V. Tetrahedron Lett. 2001, 42, 5813.

5. (a) Kira, T.; Kakefuda, A.; Shuto, S.; Matsuda, A.; Baba, M.; Shigeta, S. Nucleosides \& Nucleotides 1995, 14 (3-5), 571. (b) Tino, J. A.; Clark, J. M.; Field, A. K.; Jacobs, G. A.; Lis, K. A.; Michalik, T. L.; Mcgeeverrubin, B.; Slusarchyk, W. A.; Spergel, S. H.; Sunden, J. E.; Tuomari, A. V.; Weaver, E. R.; Young, M. G.; Zahler, R. J. Org. Chem. 1993, 36, 1221. (c) Huryn, D. M.; Sluboski, B. C.; Tam, S. Y.; Weigele. M.; Sim, I.; Anderson, B. D.; Mitsuya, H.; Broders, S. J. Med. Chem. 1992, 35, 2347.

6. Nair, V.; St. Clair, M.; Reardon, J. E.; Krasny, H. C.; Hazen, R. J.; Paff, M. T.; Boone, L. R.; Tisdale, M.; Najera, I.; Dornsife, R. E.; Everett, D. R.; Borroto-Esoda, K.; Yale, J. L.; Zimmerman, T. P.; Rideout, J. L. Antimicrob. Agents Chemother. 1995, 39, 1993.

7. Nuesca, Z. M.; Nair, V. Tetrahedron Lett. 1994, 35, 2485.

8. (a) Hoshino, H.; Shimizu, N.; Shimada, N.; Takita, T.; Takeuchi, T. J. Antibiot. 1987, 40, 1077. (b) Tino, J. A.; Clark, J. M.; Field, A. K.; Jacobs, G. A.; Lis, K. A.; Michalik, T. L.; McGeever-Rubin, B.; Slusarchyk, W. A.; Spergel, S. H.; Sundeen, J. E.; Tuomari, A. V.; Weaver, E. R.; Young, M. G.; Zahler, R. J. Med. Chem. 1993, 36, 1221.

9. (a) Vieira, E.; Vogel, P. Helv. Chim. Acta 1982, 65, 1700. (b) Vieira, E.; Vogel, P. Helv. Chim. Acta 1983, 66, 1865.

10. Black, K. A.; Vogel, P. Helv. Chim. Acta 1984, 67, 1612. 
11. Saf, R.; Faber, K.; Penn, G.; Griengl, H. Tetrahedron 1988, 44, 389.

12. (a) Pappo, R.; Allen, Jr., D. S.; Lemieux, R. L.; Johnson, W. S. J. Org. Chem. 1956, 21, 478. (b) Sells, T. B.; Nair, V. Tetrahedron 1994, 50, 117.

13. VanRheenen, V.; Kelly, R. C.; Cha, D. Y. Tetrahedron Lett. 1976, 1973.

14. Rondot, B.; Durand, T.; Rossi, J. -C.; Rollin, P. Carbohydr. Res. 1994, 261, 149.

15. Nishimura, Y; Umezawa, Y.; Adachi, H.; Kondo, S.; Takeuchi, T. J. Org. Chem. 1996, 61, 480.

16. Pickering, L; Nair, V. Nucleosides \& Nucleotides 1996, 15, 1751.

17. Purdy, D. F.; Zintek, L.; Nair, V. Nucleosides \& Nucleotides 1994, 13, 109.

18. Kakefuda, A.; Shuto, S.; Nagahata, T.; Seki, J.-I.; Sasaki, T.; Matsuda, A. Tetrahedron 1994, 50, 10167. 